\title{
Nitrogen fertilizer effect in production, nutrient accumulation and nitrogen efficiency use of second ratoon sugarcane harvested without straw burning
}

\author{
Diego Wyllyam do Vale, Renato de Mello Prado, José Reinaldo da Silva Cabral de Moraes, Flávio José \\ Rodrigues Cruz*
}

\author{
Departement of Soils and Fertilizers, Faculty of Agricultural and Veterinary Sciences, Campus Jaboticabal, São \\ Paulo State University "Júlio de Mesquita Filho", São Paulo, Brazil.
}

\author{
"Corresponding author, e-mail: fjrcpp@outlook.com
}

\begin{abstract}
Sugarcane harvest after straw burning implies rapid mineralization of biomass and greenhouse gas emissions. In this context, maintenance of sugarcane straw on the soil is as a new strategy to circumvent the harmful environmental effects, but imposes a new dynamic regarding nitrogen in the soil-plant system. This study sought to evaluate the effect of nitrogen fertilization on biomass production and nutrient accumulation in leaf (senescent and young) and stalks of sugarcane plant from the second sugarcane ratoon, variety SP 83-2847, harvested mechanically in 2007 after six years without straw burning for six years. This study adopted a randomized block design with five nitrogen doses application $\left(0,60,120,180\right.$ and $\left.240 \mathrm{~kg} \mathrm{ha}^{-1}\right)$ in the form of ammonium nitrate and four replications. Nitrogen fertilization promoted an increase in leaf (senescent and young) and stalk production of the sugarcane plants. However, excess nitrogen decreased accumulation of macro and micronutrients and nitrogen use efficiency by sugarcane due to dilution effect. Although straw deposition on the soil surface of the sugarcane field had occurred for six years, but mineralization of organic matter from the straw did not provide sufficient nitrogen for the growth of sugarcane plants in control treatments, requiring nitrogen application via fertilization. There is a need to adopt new nitrogen fertilization strategies in order to increase nitrogen use efficiency for greater production of sugarcane.
\end{abstract}

Keywords: Ammonium nitrate, mechanical harvest, $\mathrm{CO}_{2}$ emissions, organic matter, mineralization.

\section{Introduction}

Brazil is a major sugarcane producer in the world with stalk production estimated at 666.824 million tons in the 2015/2016 harvest, where the state of São Paulo is the largest Brazilian producer, responsible for 367.450 million tons (Unica, 2016). Brazilian hegemony in the production of sugarcane results from the favorable climate and soil conditions for its cultivation, and more recently to stimulus from the production of flex-fuel automobiles (Brazilian National Energetic Balance, 2010). Furthermore, sugarcane has been highlighted by the production of ethanol, due to the need to adopt clean energy by replacing fossil fuels with biofuels that have less environmental impact on the emission of greenhouse gases (EPA, 2010), however the harvest burning of sugarcane for straw removal has a significant environmental impact resulting from the large release of $\mathrm{CO}_{2}$ and negative effects on human health (Ferreira et al., 2014). Given the $\mathrm{CO}_{2}$ emissions resulting from harvest with straw burning, the largest state producer of sugarcane in Brazil, São Paulo, through the Law Decree of March 11, 2013, which regulates legislation number 11,241 of September 19, 2002, implemented the gradual replacement of harvest with straw burning for mechanical harvesting without straw removal by burning by 2017 (São Paulo, 2002). This will reduce the contribution of this practice on the greenhouse effect and also the negative health effects of the population near the fires. However, this new type of harvest shows dual benefits, where maintaining 10 to $30 \mathrm{Mg} \mathrm{ha}^{-1}$ of straw on the soil surface (Trivelin et al., 1996) on the one hand promotes beneficial effects such as increased deposition of organic matter and improved physical, chemical and biological conditions of the soil, and on the other hand may lead to an initially lower mineralization rate of organic material in the soil, since the $\mathrm{C}: \mathrm{N}$ ratio of the sugarcane straw is approximately 100 . In this case, the natural tendency is that there is greater assimilation (immobilization) of nitrogen by heterotrophic soil microflora compared to mineralization (Chen et al., 2014), and therefore extra nitrogen application is needed for initial growth of the sugarcane plant or ratoon.

However, despite the beneficial response of sugarcane to nitrogen fertilization, it must be considered that only $20 \%$ of the supplied nitrogen is effectively absorbed by this culture (Franco et al., 2011; Mariano et al., 2012) and a significant part of the nitrogen added to the soil may be lost (i.e. leaching, volatilization, etc.). It is estimated that approximately $23 \%$ of nitrogen supplied to soil by the fertilizer and residues is lost with the emission of $\mathrm{NH}_{3}-\mathrm{N}$ (Bouwman et al., 2002). This loss not only involves a reduction in the economic efficiency of nitrogen fertilizers, but also environmental damage, because the ammonia released into the atmosphere is generally deposited near the source of emission, causing acidification and eutrophication of natural ecosystems (Sommer et al., 1991).

These facts therefore suggest the adoption of new nitrogen fertilization management strategies, especially in the context of irreversible and growing implementation of green sugarcane harvest, where the maintenance of straw on the 
ground implies new dynamics regarding nitrogen in the agroecosystem of the sugarcane crop. Furthermore, because the rate of the organic matter mineralization process and availability of nitrogen are dependent on factors such as temperature, moisture content and aeration of the soil, quality and quantity of organic matter present in the soil, the C:N ratio of the crop residue and chemical and physical characteristics of the soil, nitrogen fertilization management should be considered because ratoon productivity is more responsive to increasing nitrogen doses when compared to the sugarcane plant for the purpose of high yields (Raij et al., 1996). However, literature indicates divergent studies, where some showed responses of the sugarcane ratoon to nitrogen fertilization at the nitrogen dose equal to $120 \mathrm{~kg} \mathrm{ha}^{-1}$ (Orlando Filho et al., 1999) and even higher with doses of $200 \mathrm{~kg} \mathrm{ha}^{-1}$ (Prado and Pancelli, 2008) and $245 \mathrm{~kg} \mathrm{ha}^{-1}$ (Madhuri et al., 2011), while others indicated reduced productivity resulting from straw remaining on the soil in fertilization assays (Orlando Filho et al., 1994). Therefore, it is important to perform new studies on nitrogen use efficiency to achieve high yields with greater sustainability (Ahlgren et al., 2008), which is little explored in research on the sugarcane culture submitted to nitrogen fertilization.

Due to the existence of controversial results regarding the response of the sugarcane culture to nitrogen fertilization in the green sugarcane harvest system, this study sought to evaluate the effect of nitrogen fertilization on biomass production, nutrient accumulation and use efficiency by the second sugarcane ratoon, variety SP 83-2847, harvested without straw removal by burning for six years.

\section{Results}

\section{Biomass accumulation}

Increasing nitrogen doses promoted a quadratic increase $(P<$ $0.05)$ in the biomass accumulation of senescent (Figure 2A) and green leaves (Figure 2B) and stalks (Fig 2C), reaching the maximum points of $2.37,12.1$ and $44.8 \mathrm{Mg} \mathrm{ha}^{-1}$ for the nitrogen doses of $116.7,106.5$ and $144.21 \mathrm{~kg} \mathrm{ha}^{-1}$, respectively.

\section{Nutrients accumulation in leaves and stalk}

Regarding nutrient accumulation in senescent leaves, there was an effect $(P<0.05)$ of nitrogen fertilization, observing quadratic fit only for the nutrients $\mathrm{P}, \mathrm{Ca}, \mathrm{S}, \mathrm{B}$ and Fe (Figures $3 \mathrm{~A}, \mathrm{~B}, \mathrm{C}, \mathrm{D}$ and $\mathrm{E}$ respectively). These nutrients presented maximum accumulation of $0.57 ; 3.88 ; 1.11 \mathrm{~kg} \mathrm{ha}^{-1} ; 9.0$ and $445.0 \mathrm{~g} \mathrm{ha}^{-1}$ in doses of $95 ; 215 ; 169.7 ; 108.0$ and $131.43 \mathrm{~kg}$ $\mathrm{ha}^{-1}$ de $\mathrm{N}$ respectively.

In the green leaves, nitrogen fertilization promoted a quadratic increase $(P<0.05)$ for all macronutrients (Figures $4 \mathrm{~A}, \mathrm{~B}, \mathrm{C}, \mathrm{D}, \mathrm{E}$ and $\mathrm{F}$ ) and for the micronutrients $\mathrm{B}, \mathrm{Cu}, \mathrm{Fe}$, $\mathrm{Mn}$ and $\mathrm{Zn}$ (Figures 5A, B, C, D, E and F respectively). The macronutrientes $\mathrm{N}, \mathrm{P}, \mathrm{K}, \mathrm{Ca}, \mathrm{Mg}$ and $\mathrm{S}$ had a maximum accumulation of $6.67 ; 1.54 ; 14.52 ; 2.65 ; 1.46$ and $3.13 \mathrm{~kg} \mathrm{ha}^{-1}$ for the doses of $110.3 ; 117.0 ; 124.24 ; 84.0 ; 133.3$ and 108.3 $\mathrm{kg} \mathrm{ha}^{-1}$ of $\mathrm{N}$ respectively. The micronutrients $\mathrm{B}, \mathrm{Cu}, \mathrm{Fe}, \mathrm{Mn}$ and $\mathrm{Zn}$, for its time, had a maximum accumulation of 2.45 ; $4.10 ; 227.2 ; 97.30$ and $16.12 \mathrm{~g} \mathrm{ha}^{-1}$ for the doses of 81.0 ; $89.5 ; 137.41 ; 107.2$ and $119.4 \mathrm{~kg} \mathrm{ha}^{-1}$ of $\mathrm{N}$ respectively.

With respect to the stalk, nitrogen fertilization resulted in a quadratic increase $(P<0.05)$ only for the accumulation of $\mathrm{N}$, $\mathrm{P}$ and $\mathrm{Mn}$, and linear for $\mathrm{B}$ accumulation (Figures 6A, B, C and $\mathrm{D}$ respectively). The nutrients $\mathrm{N}, \mathrm{P}$ and $\mathrm{Mn}$ had a maximum accumulation of 98.65 and $10.26 \mathrm{~kg} \mathrm{ha}^{-1}$ and
$4088.3 \mathrm{~g} \mathrm{ha}^{-1}$ for the doses of $166.5 ; 124.83$ and $128.96 \mathrm{~kg}$ $\mathrm{ha}^{-1}$ of $\mathrm{N}$ respectively. Considering the nitrogen dose of 153.8 $\mathrm{kg} \mathrm{ha}^{-1}$ relative to maximum dry matter accumulation of the stalk (44.1 $\mathrm{Mg} \mathrm{ha}^{-1}$ ), was observed the following order of nutrient accumulation in senescent leaves: $\mathrm{Ca}>\mathrm{S}>\mathrm{P}>\mathrm{Fe}>\mathrm{B}$; green leaves: $\mathrm{K}>\mathrm{N}>\mathrm{S}>\mathrm{Ca}>\mathrm{Mg}>\mathrm{P}>\mathrm{Fe}>\mathrm{Mn}>\mathrm{Zn}>\mathrm{Cu}>\mathrm{B}$ and stalk: $\mathrm{N}>\mathrm{P}>\mathrm{Mn}>\mathrm{B}$.

\section{Nitrogen use efficient}

The nitrogen use efficiency (NUE) by second ratoon varied with $\mathrm{N}$ doses. There were quadratic response of NUE in the $\mathrm{N}$ doses $(P<0.05)$. The maximum NUE was $18.04 \mathrm{~kg}$ DM $\mathrm{kg}^{-1} \mathrm{~N}$ for the doses of $121.3 \mathrm{~kg} \mathrm{ha}^{-1}$ of $\mathrm{N}$ (Figure 7). Above this dose NUE was considerably reduced with averages close to the value presented by the control treatment.

\section{Correlation between nutrient and biomass accumulation}

A significative correlation $(P<0.05)$ only was observed between stalk biomass and phosphorus $(r=0.83)$ and nitrogen accumulation $(r=0.78)$. Excetuando-se $\mathrm{Mg}(r=$ $0.60)$ e $\mathrm{S}(r=0.68)$, the others nutrients presented lower correlation in relation stalk biomass. The high nitrogen doses imply greater vegetative growth of sugarcane, especially stalk biomass (Table 2).

\section{Discussion}

Although nitrogen fertilization is an important strategy to increase productivity and longevity of sugarcane ratoons (Vitti et al., 2007), the response of ratoons to nitrogen supply is quite controversial, independent of the straw management system (i.e., with or without straw burning). Despite six years of deposition of straw on the ground and the supply of nitrogen fertilizer, the response of sugarcane growth was similar to other studies reported in the literature. For example, Orlando Filho et al. (1994) found considerable differences in response of the third ratoon of variety SP716163 between the management systems of burnt sugarcane and green sugarcane harvest, observing the higher response in the former system when compared to the latter for the variables production and number of stalks, both at 60 and 90 days of age. However, in present study, despite the increase in biomass production of stalks in function of nitrogen fertilization, it was lower compared to other studies involving the third ratoon. It is important to emphasize that the reduced rainfall registered between the months of May and September may have contributed to lower productivity of the second ratoon. The rainfall it was lower than the average of the other months (Figure 1). Cantarella et al. (2008) in study with varieties SP83-2847 got $122 \mathrm{Mg} \mathrm{ha}^{-1}$ using the dose of $100 \mathrm{~kg}$ $\mathrm{ha}^{-1} \mathrm{~N}$ as ammonium sulfate, while Costa et al. (2003) in study with application of nitrogen source uran $(32 \% \mathrm{~N})$ obtained stem production of $50.7 \mathrm{Mg} \mathrm{ha}^{-1}$ in the variety SP 80-1842.

In the present study, despite successive nitrogenous fertilizer was observed reduction in stalk production which was 97; 71 and $44 \mathrm{Mg} \mathrm{ha}^{-1}$ for sugarcane plant, first and second ratoon respectively (see in materials and methods section). This pattern of productivity of sugarcane appears to be related to the genetic characteristics of each genotype, as well as the interaction between environment and genotype (Silveira et al., 2013). Environmental factors related to growth of plants such as light, temperature, nutrients and water availability, in addition to intrinsic factors related to the genotype as budding, tillering capacity, age and activity of the root system 
Table 1. Physical and chemical attributes of soil after installation of the experiment in 2007.

\begin{tabular}{|c|c|c|c|c|c|c|c|c|c|c|}
\hline Layer & $\mathrm{OM}^{1}$ & $\mathrm{P}$ & $\mathrm{K}$ & $\mathrm{Ca}$ & $\mathrm{Mg}$ & $\mathrm{H}+\mathrm{Al}$ & $\mathrm{Al}$ & $\mathrm{CEC}^{3}$ & $\mathrm{M}^{4}$ & $\mathrm{~V}^{5}$ \\
\hline (m) & $\left(\mathrm{g} \mathrm{dm}^{-3}\right)$ & 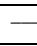 & & & $(\mathrm{mm}$ & $\left.m^{-3}\right)-$ & & & $(\%)$ & \\
\hline $0.00-0.10$ & 28 & 6 & 1.1 & 36 & 8 & 20 & 0.1 & 67.1 & 0.20 & 69 \\
\hline $0.10-0.20$ & 24 & 5 & 0.6 & 30 & 7 & 22 & 0.1 & 59.6 & 0.30 & 63 \\
\hline $0.20-0.40$ & 15 & 5 & 0.5 & 11 & 3 & 31 & 0.4 & 45.5 & 21.6 & 32 \\
\hline $0.40-0.60$ & 13 & 4 & 0.3 & 6 & 2 & 34 & 0.6 & 42.3 & 45.0 & 18 \\
\hline $0.60-0.80$ & 11 & 4 & 0.3 & 4 & 1 & 28 & 0.6 & 33.3 & 55.1 & 15 \\
\hline $0.80-1.00$ & 10 & 4 & 0.0 & 3 & 1 & 31 & 0.7 & 35.0 & 66.1 & 11 \\
\hline
\end{tabular}

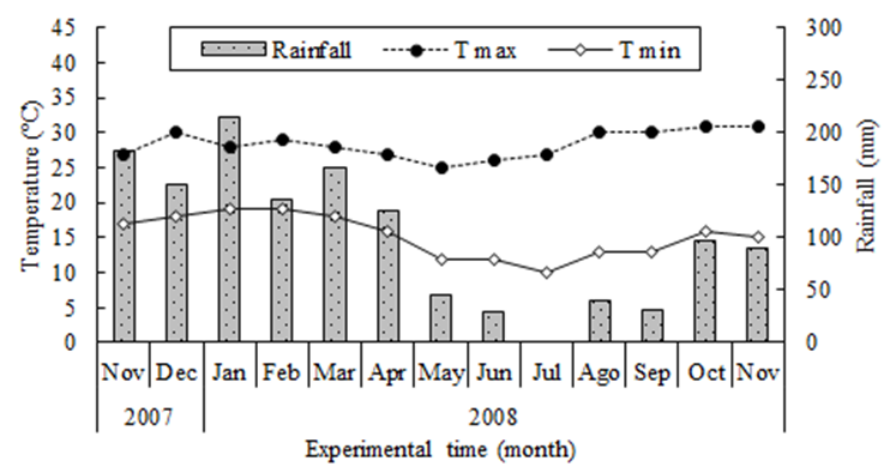

Fig 1. Monthly averages of rainfall, minimum and maximum temperature during the experimental period.

Table 2. Correlation analysis between stalk production and nutrients accumulation in sugarcane stalks of the second ratoon in nitrogen-fertilized Rhodic Ferralsol. The number represent determination coefficient ( $r$ ) at the 5\% probability.

\begin{tabular}{|c|c|c|c|c|c|c|c|c|c|c|c|}
\hline \multirow[b]{3}{*}{$\begin{array}{l}\text { Stalk production } \\
\left(\mathrm{Mg} \mathrm{ha}^{-1}\right)\end{array}$} & \multicolumn{11}{|c|}{ Stalk nutrient accumulation } \\
\hline & \multicolumn{6}{|c|}{$\mathrm{kg} \mathrm{ha}^{-1}$} & \multicolumn{5}{|c|}{$\mathrm{g} \mathrm{ha}^{-1}$} \\
\hline & $\begin{array}{l}\mathrm{N} \\
0.77\end{array}$ & $\begin{array}{l}\mathrm{P} \\
0.82\end{array}$ & $\begin{array}{l}\mathrm{K} \\
0.42\end{array}$ & $\begin{array}{l}\mathrm{Ca} \\
0.42\end{array}$ & $\begin{array}{l}\mathrm{Mg} \\
0.60\end{array}$ & $\begin{array}{l}S \\
0.68\end{array}$ & $\begin{array}{l}\mathrm{B} \\
0.19\end{array}$ & $\begin{array}{l}\mathrm{Cu} \\
0.51\end{array}$ & $\begin{array}{l}\mathrm{Fe} \\
0.51\end{array}$ & $\begin{array}{l}\mathrm{Mn} \\
0.08\end{array}$ & $\begin{array}{l}\mathrm{Zn} \\
0.19\end{array}$ \\
\hline
\end{tabular}
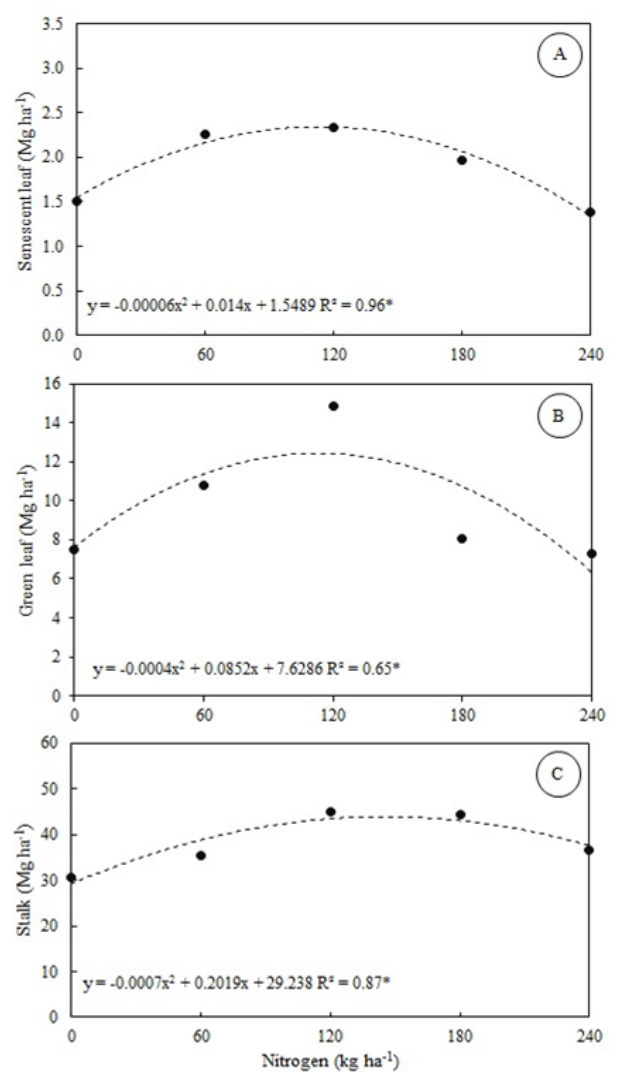

Fig 2. Nitrogen fertilization effect in biomass in the sugarcane production of second ratoon cultivated in Rhodic Ferralsol and without straw burning. Senescent (A) and green (B) +1 leaf and stalk (C). * Significant at $5 \%$ of probability. 

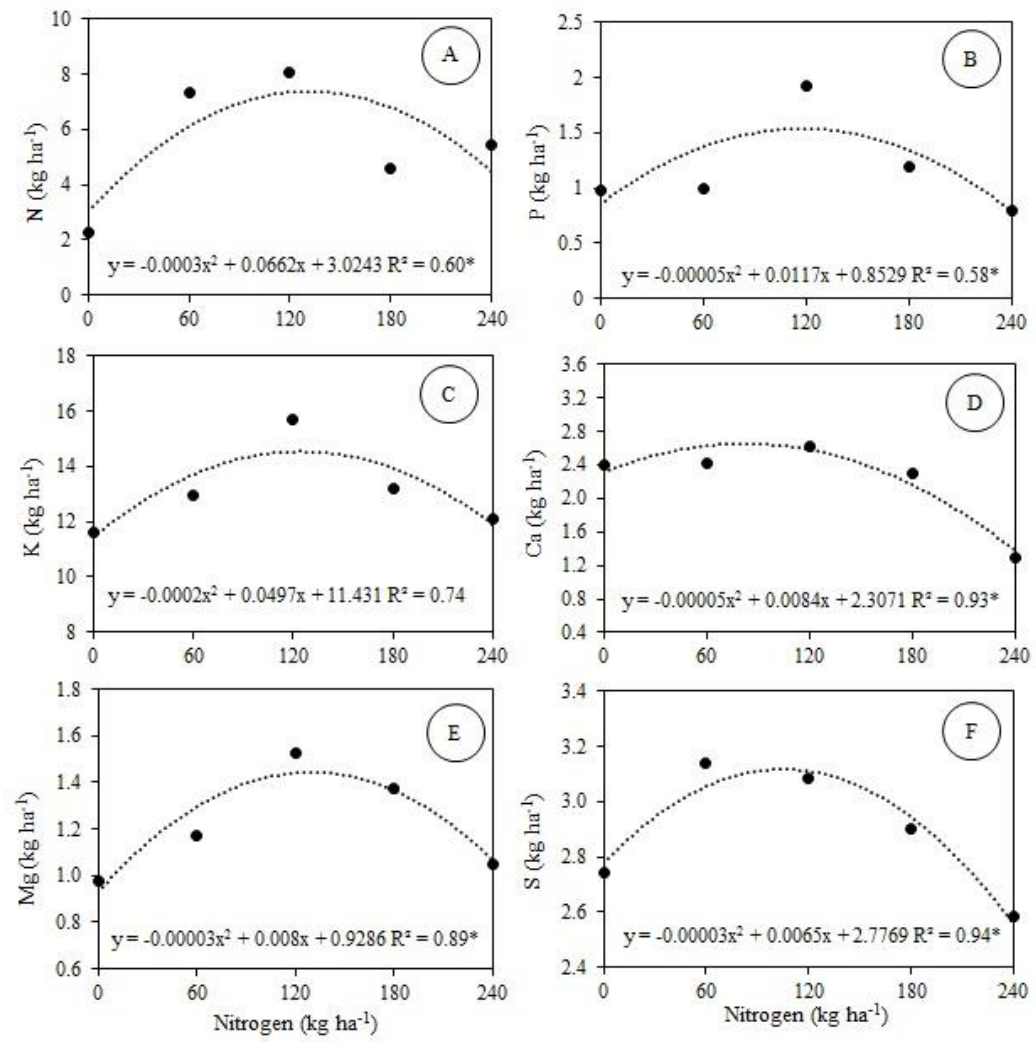

Fig 3. Nitrogen fertilization effect in senescent leaf $(+1)$ nutrients accumulation in the sugarcane of second ratoon cultivated in Rhodic Ferralsol and without straw burning. Phosphorous (A), calcium (B) sulphur (C) boron (D) and iron (E) nutrient. * Significant at $5 \%$ probability by $\mathrm{F}$ test.
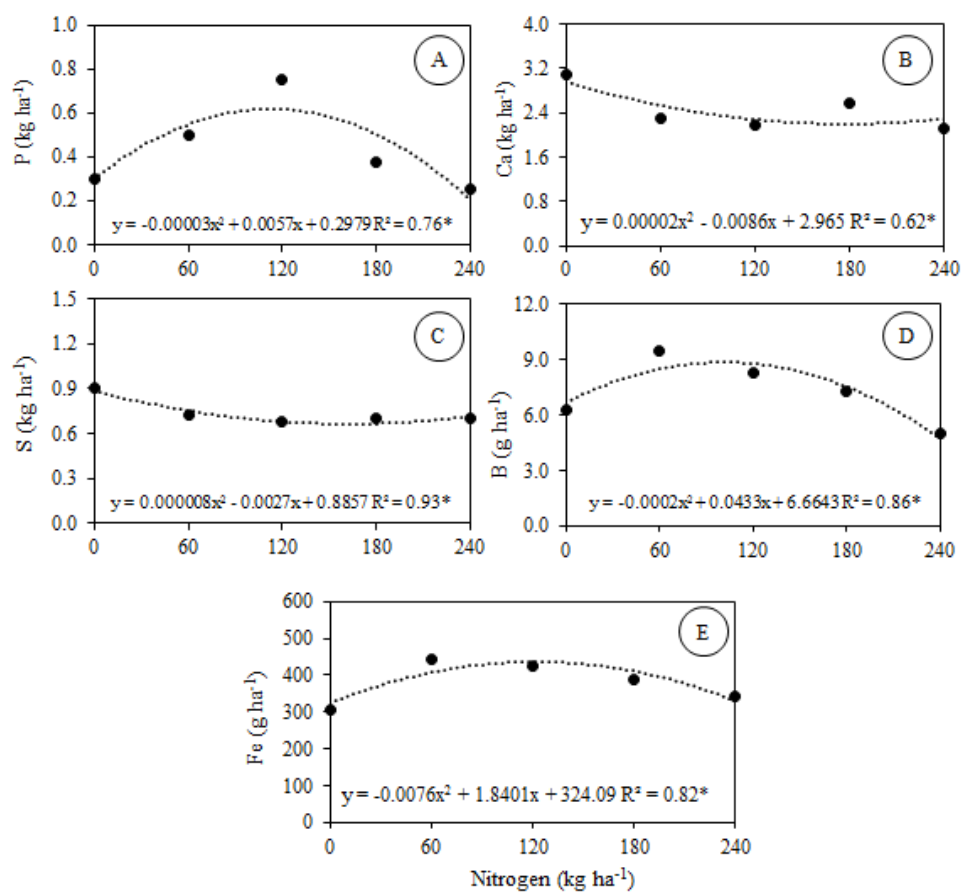

Fig 4. Nitrogen fertilization effect in green leaf $(+1)$ nutrients accumulation in the sugarcane of second ratoon cultivated in Rhodic Ferralsol and without straw burning. Nitrogen (A), phosphorous (B), potassium (C), calcium (D), magnesium (E) and sulfur (F). * Significant at $5 \%$ probability by $\mathrm{F}$ test. 

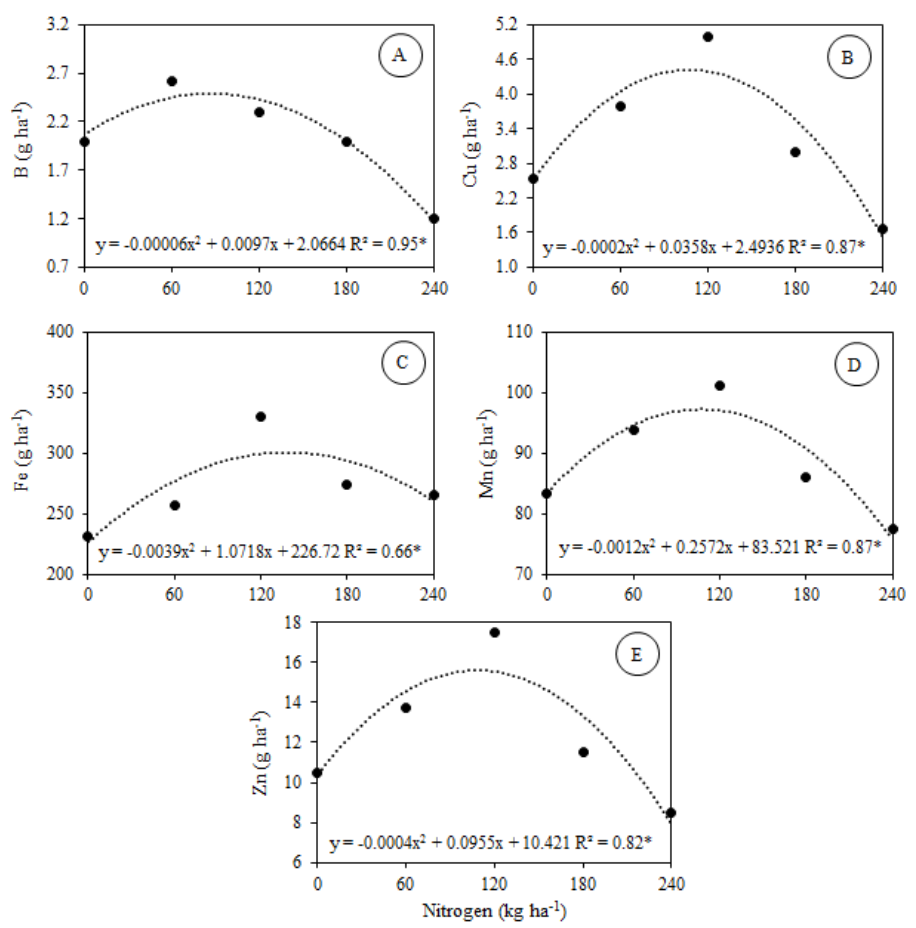

Fig 5. Nitrogen fertilization effect in green leaf $(+1)$ nutrients accumulation in the sugarcane of second ratoon cultivated in Rhodic Ferralsol and without straw burning. Boron (A), copper (B), iron (C), manganese (D) and zinc. * Significant at $5 \%$ probability by $\mathrm{F}$ test.
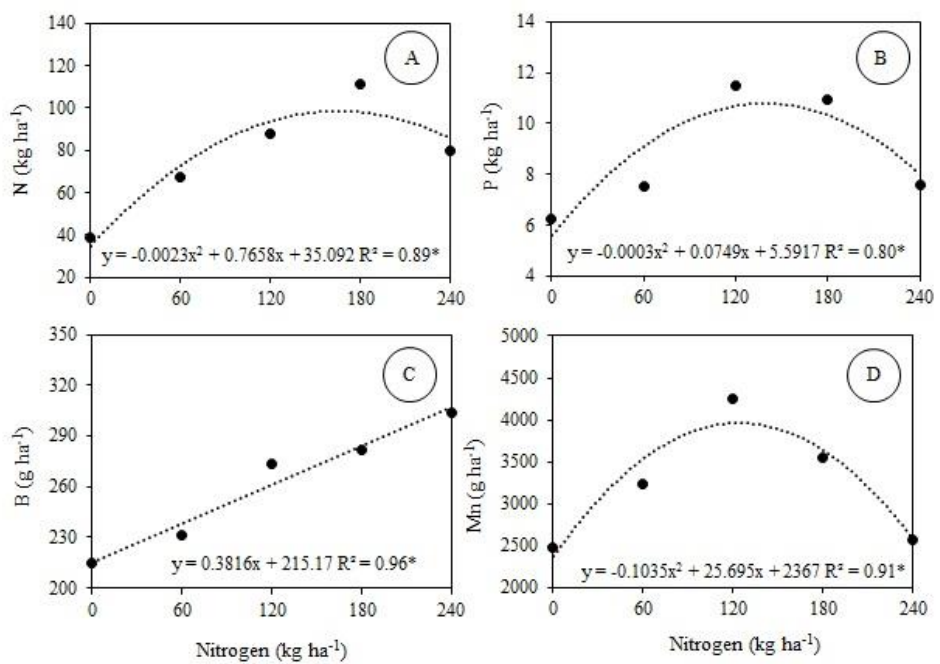

Fig 6. Nitrogen fertilization effect in stalks nutrients accumulation in the sugarcane of second ratoon cultivated in Rhodic Ferralsol and without straw burning. Nitrogen (A), phosphorous (B), boron (C) and manganese (D). * Significant at 5\% probability by F test.

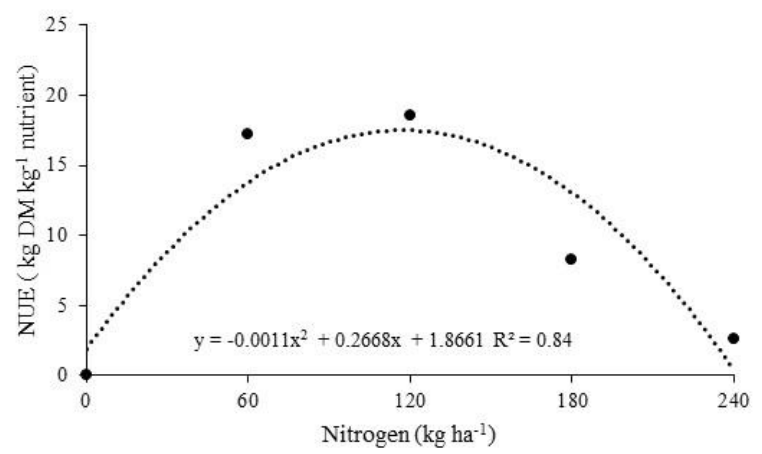

Fig 7. Nitrogen fertilization effect in nitrogen use efficient (NUE) by sugarcane of the second ratoon cultivated in Rhodic Ferralsol and without straw burning. Nitrogen (A), phosphorous (B), boron (C) and manganese (D). * Significant at $5 \%$ probability by $\mathrm{F}$ test. 
also contribute to reduced productivity among successive crops (Lima et al., 2006; Dinardo-Miranda et al., 2008), although the genetic capacity of production of sugarcane is $300 \mathrm{Mg} \mathrm{ha}^{-1}$ (Albuquerque and Silva, 2008). However, the sugarcane production in present study suggest that only six years of adoption of the sugarcane harvest without burning was not enough to reduce the supply of nitrogen fertilization. For this, it is necessary that the processes of immobilization and mineralization of the straw of nitrogen were in balance, so that the nitrogen was used for sugarcane. However only $4 \%$ of $\mathrm{N}$-mineralization of straw sugarcane is used by sugarcane ratoon per year (Gava et al., 2003).

It is important to note that literature reports low nitrogen recovery in both the sugarcane plant and sugarcane ratoon. This fact was demonstrated by Gava et al. (2003), who in variety SP81-3250 found use of nitrogen fertilization with labeled urea $\left({ }^{15} \mathrm{~N}\right)$ in the ratoon only of 10 to $16 \%$ of the total accumulated nitrogen in the entire plant, while the labeled and mineralized nitrogen in the straw was only $4 \%$. Thus, low nitrogen recovery for sugarcane without burning harvesting system suggests the need for nitrogen fertilization in this crop due to high $\mathrm{C}: \mathrm{N}$ ratio of straw. In addition, although the supply of nitrogen for higher yield $\left(120 \mathrm{~kg} \mathrm{ha}^{-1}\right.$ $\mathrm{N})$ there were no increases in production of stalk in larger doses of N (Figure 3C). Similarly to date reached in the study, Singh and Yadav (1996) reported reduction in cane yield due to higher nitrogen fertilizer, and higher nitrogen make stalk succulent and soft which become more susceptible to pests and diseases (Gopalasundaram et al., 2012).

The macro and micronutrient accumulation in the dry and green leaves and stalk increased with the supply of nitrogen. However, there was reduction in accumulation of nutrients in the evaluated organs, considering the dose of nitrogen above the dose corresponding to the maximum accumulation of the respective nutrients evaluated, except $\mathrm{B}$ in the stalk. These results followed the pattern of production observed in stalk, dry and green mass of leaves, supposedly due to excessive vegetative growth induced by nitrogen fertilization, which resulted in the appearance of the dilution effect (Jarrell and Beverly, 1981).

The evaluation of nutrient accumulation in the senescent and green leaves and stalk allows to evaluate the nutritional balance of plant shoots and thus predict the amount of nutrients that will be maintained in the straw (senescent and green leaves) and exported by stalk harvest. This study indicated the large export of mobile nutrients in the stalk $(\mathrm{N}$, $\mathrm{P}, \mathrm{Mn}$ and B) (Figure 6), however, a significant quantity of macronutrients, in particular $\mathrm{N}$ and $\mathrm{P}$, during the maturation stage was redistributed from the leaf to stalk tissues and exported at harvest. This is reinforced by the high correlation between the accumulation of $\mathrm{N}(r=0.77)$ and $\mathrm{P}(r=0.88)$ in the stalk and the production of this organ. Thus, the nitrogen fertilization showed essential for the growth of sugarcane, although in this study, the adoption of harvest without fire has been adopted six years ago.

The present study showed that the remaining straw, resulting from six years of the green sugarcane harvest system after renewal of the sugarcane fields, was insufficient to provide the nitrogen needed for growth of the second ratoon due to large export of nitrogen, low decomposition and mineralization of straw. This fact is indicated by the reduced production of dry and green leaves and stalk of the control treatment. However, despite the accumulation of important nutrients in the leaves, leaf decomposition and mineralization was compromised by the high C:N ratio of sugarcane (Gopalasundaram et al., 2012), although the mineralization of organic matter is a significant source of $\mathrm{N}$ in the production of first-cycle sugarcane (Gava et al., 2003; Franco et al., 2011).

Thus, the management of nitrogen fertilization is a necessary strategy when the objective is high productivity gains in the sugarcane agro-ecosystem, which gradually adapts to the green harvesting system that imposes a new dynamic regarding nitrogen in the soil-plant system, that the long term still require the input of nitrogen fertilizer. It is important to emphasize this fact because reduction in productivity of sugarcane results from intrinsic and extrinsic factors (Lima et al., 2006; Dinardo-Miranda et al., 2008), which was observed in this study, where reduction in the productivity of plant cane, first and second ratoon were 97 , 71 and $44 \mathrm{Mg} \mathrm{ha}^{-1}$, respectively, was reached.

\section{Materials and methods}

\section{Characteristics of experimental sites and plant material}

The experiment was carried in the city of Matão, São Paulo State, Brazil in Rhodic Ferralsol (IUSS Working Group WRB, 2006), situated at $21^{\circ} 33^{\prime} \mathrm{S}$ latitude and $48^{\circ} 18^{\prime \prime} \mathrm{W}$ longitude. Meteorological data were obtained for the maximum and minimum temperatures and rainfall during the entire experimental period (Figure 1). The Sugarcane variety evaluated was SP 83-2847 which is characterized by its fast and decumbent growth.

\section{Experimental design and treatments}

The experiment was setup in a randomized block design with five treatments represented by the nitrogen doses and four replications. The experimental unit consisted of plots with five rows of sugarcane measuring $15 \mathrm{~m}$ long, spaced at $1.5 \mathrm{~m}$, totaling $112.5 \mathrm{~m}^{2} \mathrm{plot}^{-1}$. The three central rows were considered as the useful area, with a $2 \mathrm{~m}$ corridor between the front of the plots and $4.5 \mathrm{~m}$ between the lateral sides of the plots, totaling an experimental area of $4136 \mathrm{~m}^{2}$. The experiment was set up immediately after harvesting the second sugarcane ratoon. Treatments consisted of applying the doses of $0,60,120,180$ and $240 \mathrm{~kg} \mathrm{ha}^{-1}$ of ammonium nitrate $\left(\mathrm{NH}_{4} \mathrm{NO}_{3}-35 \% \mathrm{~N}\right)$, where the intermediate dose $(120$ $\left.\mathrm{kg} \mathrm{ha}^{-1}\right)$ is indicated for maximizing production of the sugarcane ratoon in the state of São Paulo (Raij and Cantarella, 1997).

\section{History of the experimental site}

The experimental site was initially planted with soybeans and in 2001 sugarcane cultivation began, utilizing the green sugarcane harvest system. In 2004/2005, the sugarcane plants were reformed by rotation with soybeans followed by planting of the variety SP 83-2847 in 2005. In november of 2007 the second ratoon experiment was began and in november of 2008 the experiment was finish. The experimental site was chosen because sugarcane has always been harvested mechanically since 2001. This area was submitted to conventional tillage during renovation of the sugarcane plantation along with lime application $(\mathrm{CaO}=42 \%$ and $\mathrm{MgO}=7 \%$ ) in order to the raise base saturation value to $70 \%$. In the first sugarcane harvest, $435 \mathrm{~kg} \mathrm{ha}^{-1}$ of NPK (2700-24) was applied and the production of stalk obtained was $97 \mathrm{Mg} \mathrm{ha}^{-1}$. In the second sugarcane harvest, or the first ratoon, the area was fertilized with $439 \mathrm{~kg}$ of NPK (27-00$24)$, resulting in stalk production of $71 \mathrm{Mg} \mathrm{ha}^{-1}$. 


\section{Soil characterization, second ratoon fertilization and straw sampling}

Before implementation of this experiment in november 2007, 15 soil subsamples were collected to make up the composite sample, at the layers of $0-10,10-20$ and $20-40 \mathrm{~cm}$ deep. The samples were broken-up and sieved through a $4 \mathrm{~mm}$ mesh for conducting the soil chemical (Raij et al., 2001) (Table 1). Fertilizer was applied about $10 \mathrm{~cm}$ from the line of ratoon in full budding in december of 2007, one month after sugarcane harvest of first ratoon in november of 2007. During fertilization, in addition to $\mathrm{NH}_{4} \mathrm{NO}_{3}$ also applied was potassium to all treatments at a dose of $150 \mathrm{~kg} \mathrm{ha}^{-1} \mathrm{~K}_{2} \mathrm{O}$ $(\mathrm{KCl})$. Chemical analysis of the soil (Table 1) did not indicate the need for phosphorus application according to phosphorus fertilizer recommendations for sugarcane (Raij and Cantarella, 1997). Three random $1 \mathrm{~m}^{2}$ samples were collected of the straw remaining on the soil, estimating a mass of 12 $\mathrm{Mg} \mathrm{ha}^{-1}$ after drying in a forced ventilation oven at $65^{\circ} \mathrm{C}$.

\section{Sampling and measurements}

Green harvest of the second sugarcane ratoon was performed manually in november of 2008, considering the useful area as one linear meter of the center row. The senescent and green leaves were detached from the stalks and the samples were weighed to determine the fresh mass. Then the samples were placed to dry in a forced circulation oven at $65^{\circ} \mathrm{C}$ until reaching constant weight followed by grinding in a mill.

The $\mathrm{N}$ in the leaves was mineralized in sulfuric digestion and dosed using the micro Kjeldahl method (Malavolta et al., 1997). The other nutrients were mineralized in nitroperchloric digestion and the extracts obtained were measured by the following methods: The $\mathrm{P}$ was analyzed calorimetrically in according molybdate method; The $\mathrm{K}$ by flame photometry; The $\mathrm{Ca}, \mathrm{Mg}, \mathrm{Mn}, \mathrm{Zn}, \mathrm{Fe}$ e $\mathrm{Cu}$ by atomic absorption spectrophotometry; the $\mathrm{S}$ by turbidimetry and $\mathrm{B}$ by digestion via incineration method. All chemical analyses were performed in according to method proposed by Bataglia et al. (1983). Nutrient accumulation was determine by product between biomass production and nutrient content, and nitrogen use efficiency was determined according with Fageria et al. (1997). See (1), (2) and (3) expressions below:

$$
\begin{array}{r}
N U E=P E \times N E R \\
P E=\frac{(Y n f-Y w f)}{(N n f-N w f)} \\
N E R=\frac{(Q n f-Q w f)}{N f a} \times 100
\end{array}
$$

Where:

$N U E$, nitrogen use efficiency ; $P E$, physiology efficiency; NER, nitrogen efficiency recovery; $Y n f$, plant production with fertilizer; $Y w f$, plant production without fertilizer; Nnf and Qnf, nutrient accumulate with fertilizer; $N w f$ and $Q w f$, nutrient accumulate without fertilizer; $Q n$, amount of fertilizer applied.

\section{Statistical analyses}

The data were analysed by analysis of variance (ANOVA) at a significant level of 5\%. The polynomial regression analysis was adopted to determine relationships between the measured parameters. The choice of the polynomial function was based in higher and significant determination coefficient $\left(\mathrm{R}^{2}\right)$. A correlation analysis $(r)$ at $5 \%$ was adopted to assess the degree of intensity of the relationship between stalk growth and nitrogen accumulation.

\section{Conclusion}

This study evaluated the effect of nitrogen fertilization on the production and accumulation for the second ratoon of sugarcane. Nitrogen fertilization promoted an increase in sugarcane production however decreased the accumulation of macro and micronutrients in leaf (green and senescent) and stalk when nitrogen doses exceeded $120 \mathrm{~kg} \mathrm{ha}^{-1}$ (dose for higher productivity) due to dilution effect. Despite straw deposit on the soil of the sugarcane field, mineralization of organic matter from the straw did not provide sufficient nitrogen for plant growth of sugarcane in the control treatment, requiring nitrogen application via fertilization. This study revealed the adoption need of new strategies of nitrogen fertilization in order to increase nitrogen use efficiency for greater production gains, given the new dynamics of nitrogen in the soil-plant system of the green sugarcane harvest system.

\section{Acknowledgements}

This study was supported by São Paulo Research Foundation (Fundação de Amparo à Pesquisa do Estado de São Paulo FAPESP) for granting the Master's scholarship to the first author (process no. 2007/53548-2).

\section{References}

Albuquerque ACS, Silva AS (2008) Agricultura tropical: quatro décadas de inovação tecnológica, institucional e política. Embrapa, Brasília, DF: Informação Tecnológica.

Ahlgren S, Baky A, Bernesson S, Nordberg A, Norén O, Hansson P (2008) Ammonium nitrate fertilizer production based on biomass - Environmental effects from a life cycle perspective. Bioresource Technol. 99 (17): 8034-8041.

Bataglia OC, Furlani AMC, Teixeira JPF, Furlani PR, Gallo JR (1983). Métodos de análise química de plantas. Instituto Agronômico de Campinas, São Paulo. (Boletim Técnico, 78). Available online at: http://agris.fao.org/openagris/search.do?recordID=BR19 840098851 (Accessed February 3, 2017).

Bouwman AF, Boumans LJM, Batjes NH (2002) Estimation of global $\mathrm{NH}_{3}$ volatilization loss from synthetic fertilizers and animal manure applied to arable lands and grasslands. Glob Biogeochem Cycles. 16 (2): 1-8.

Brazilian National Energetic Balance (2010) Brazil, Ministry of Mines and Energy. Available online at: https://ben.epe.gov.br/. (Accessed 10.07.2016)

Chen B, Liu E, Tian Q, Yan C, Zhang Y (2014) Soil nitrogen dynamics and crop residues. A review. Agron Sustain Dev. 34 (2): 429-442.

Cantarella H, Trivelin PCO, Contin TLM, Dias FLF, Rossetto R, Marcelino R, Coimbra RB, Quaggio JA (2008) Ammonia volatilization from urease inhibitortreated urea applied to sugarcane trash blankets. Sci Agr. 65 (4): 397-401.

Costa MCG, Vitti GC, Cantarella H (2003) N-NH 3 losses from nitrogen sources applied over unburned sugarcane straw. Rev Bras Cienc Solo. 27 (4): 631-637.

Dinardo-Miranda LL, Vasconcelos ACM, Landell MGA (2008) Sugarcane. Instituto Agronômico de Campinas, São Paulo.

EPA - Environmental Protection Agency (2010) Renewable fuel standard program (RFS2) regulatory impact analysis. Assessment and Standards Division, Office of Transportation and Air Quality; EPA-420-R-10e006. Available online at: 
http://www3.epa.gov/otaq/renewablefuels/420r10006.pdf (accessed 01.07.2016).

Fageria NK, Baligar VC, Allan Jones C (1997) Growth and mineral nutrition of field crops. 2nd ed, New York: Marcel Dekker.

IUSS Working Group WRB (2006) World Reference Base for Soil Resources, 2nd edn, World Soil Resources Reports no 103, UN Food and Agriculture Organization, Rome.

Ferreira LEN, Muniz BV, Bittar TO, Berto LA, Figueroba SR, Groppo FC, Pereira AC (2014) Effect of particles of ashes produced from sugarcane burning on the respiratory system of rats. Environ Res. 135: 304-310.

Franco HCJ, Otto R, Faroni CE, Vitti AC, Oliveira ECA, Trivelin PCO (2011) Nitrogen in sugarcane derived from fertilizer in Brazilian field conditions. Field Crop Res. 121 (1):29-41

Franco HCJ, Trivelin PCO, Faroni CE, Vitti AC, Otto R (2008) Utilization by sugar cane of nitrogen applied at planting. Rev Bras Cienc Solo. 32: 2763-2770.

Gaju O, Allard V, Martre P, Snape JW, Heumez E, LeGouis J, Moreau D, Bogard M, Griffiths S, Orfordd S, Hubbart S, Foulkes MJ (2011) Identification of traits to improve the nitrogen-use efficiency of wheat genotypes. Field Crop Res. 123 (2): 139-152.

Gava GJC, Trivelin PCO, Vitti AC, Oliveira MW (2003) Recovery of nitrogen $\left({ }^{15} \mathrm{~N}\right)$ from urea and cane trash by sugar cane ratoon (Saccharum spp.). Rev Bras Cienc Solo. 27 (4): 621-630.

Gopalasundaram P, Bhaskaran A, Rakkiyappan P (2012) Integrated Nutrient Management in Sugarcane. Sugar Tech. 14 (1): 3-20.

Jarrell WM, Beverly RB (1981) The dilution effect in plant nutrition studies. Adv Agron. 34: 197-224.

Kist V, Silveira G, Costa PMA, Oliveira MW, Barbosa MHP (2015) Nutrient use efficiency in sugarcane cultivars. Científica 43 (2): 117-125.

Lima SAA, Silva IF, Santiago RD, Neto LF, Souza C, Cavalcante FS (2006) Influência da adubação mineral sobre três cultivares de cana-de-açúcar na microrregião de Guarabira na Paraíba. Agropecu Técnica 27(2): 92-99.

Madhuri KV, Kumarm MH, Sarala NV (2011) Influence of Higher Doses of Nitrogen on Yield and Quality of Early Maturing Sugarcane Varieties. Sugar Tech. 13 (1): 96-98.

Mariano E, Trivelin PCO, Vieira-Megda MX, Leite JM, Otto R, Franco HCJ (2012) Ammonia losses estimated by an open collector from urea applied to sugarcane straw. Rev Bras Cienc Solo. 36 (2): 411-419.

Marschner H (2004) Beneficial mineral elements. In: Marschner H (Ed) Mineral Nutrition of Higher Plants, Academic Press ltd, San Diego.

Oliveira ECA, Freire FJ, Oliveira RI, Oliveira AC, Freire MBGS (2011) Accumulation and allocation of nutrients in sugarcane. Rev Cienc Agron. 42 (3): 579-588.

Orlando Filho J, Carmello QAC, Peixe CA., Glória AM (1994) Fertilization of ratoon sugarcane under two types of detrash: Raw x burnt sugarcane. STAB. 12: 7-11.

Orlando Filho J, Rodella AA, Beltrame JA, Lavorenti NA (1999) Doses, sources and forms of nitrogen application in sugarcane. STAB. 17: 39-41.
Prado RM, Pancelli MA (2008) Sugarcane ratoon response to nitrogen application in a no burn harvesting system. Bragantia. 67 (4): 951-959.

Raij BV, Andrade JC, Cantarella H, Quaggio JA (2001) Chemical analysis for evaluation of the fertility of tropical soils. Instituto Agronômico de Campinas, São Paulo.

Raij BV, Cantarela H, Quaggio JA, Furlani AMC (1996) Recommendations fertilization and liming for the State of São Paulo, 2rd edn. Instituto Agronômico de Campinas, São Paulo.

Raij BV, Cantarella H (1997) Other industrial crops. In: Raij BV, Cantarella H, Quaggio JA, Furlani AMC (ed) Recommendations fertilization and liming for the State of São Paulo, 2rd edn. Instituto Agronômico de Campinas, São Paulo.

São Paulo (2002) Secretary agriculture law number 11.241, September 19. It provides for the gradual elimination of straw burning of sugarcane and gives related measures. Available online at: http://www.al.sp.gov.br/legislacao/ (Accessed 15.07.2016).

Silveira LCI, Kist V, Paula TOM., Barbosa MHP, Peternelli LA, Daros E (2013) AMMI analysis to evaluate the adaptability and phenotypic stability of sugarcane genotypes. Sci Agr. 70 (1): 27-32.

Singh GB, Yadav DV (1996) Plant nutrient supply needs, efficiency and policy issues for sugarcane for the years 2000-2005. In: Kanwar JS, Katyal, JC (Ed) Proceedings of symposium on plant nutrient supply needs, efficiency and policy issues: 2000-2025, New Delhi, India. National Academy of Agricultural Sciences.

Sommer SG, Olesen JE, Christensen BT (1991) Effects of temperature, wind speed, and air humidity on ammonia volatilization from surface-applied cattle slurry. J Agr Sci. 117 (1): 91-100.

Trivelin, PCO, Rodriguês JCS, Victoria RL, Reichardt K (1996) Utilization by early harvest sugar cane ratoon of the nitrogen from $15 \mathrm{~N}$-aqua ammonia and $15 \mathrm{~N}$-urea applied to the soil as vinasse $\mathrm{N}$-complement. Pesqui Agropecu Bras. 31: 89-99.

Unica - União da Indústria de Cana-de-açúcar (2016). Available online at: http://www.unica.com.br/?idioma=1 (Accessed 04.07.2016)

Vitti AC, Trivelin PCO, Gava GJC, Penatti CP, Bologna IR, Faroni CE, Franco HCJ (2007) Sugar cane yield related to the residual nitrogen from fertilization and the root system. Pesqui Agropecu Bras. 42 (2): 249-256. 